\title{
KRITIK PROYEK JUSTICE FOR THE POOR
}

\author{
Widodo Dwi Putro \\ Fakultas Hukum Universitas Mataram di Lombok \\ Email: widodo.dwipurto@yahoo.co.id
}

\begin{abstract}
The repressive law approach in a capitalist society is becoming obsolete and turn to the legal system that more responsive and humane. As criticism-self-criticism, Socio-Legal approach which was originally a critical approach to the weakness of Legal Positivism. In development is also absorbed by capitalism to modify their projects to become more humane and responsive. In this paper, a kind of humanitarian law project is not much different from the neo-colonialism. Critics of capitalism actually needs to modify itself in such a way that the wave of protests actually have the effect of fixing. The power projects and responsive humanitarian law as justice for the poor, able to integrate resistance to capitalism in the system.
\end{abstract}

\section{Key words: ideology, capitalism, justice for the poor}

\begin{abstract}
Abstrak
Pendekatan hukum represif dalam masyarakat kapitalis mulai ditinggalkan dan beralih ke tatanan hukum yang lebih responsif dan humanis. Sebagai kritik-otokritik, pendekatan Socio-Legal yang semula merupakan pendekatan kritis atas kelemahan Positivisme Hukum. Dalam perkembangannya juga diserap oleh kapitalisme untuk memodifikasi proyek-proyek mereka sehingga menjadi lebih humanis dan responsif. Dalam tulisan ini proyek hukum humanis semacam ini tak jauh beda dengan neo-kolonialisme. Kritik justru dibutuhkan oleh kapitalisme untuk memodifikasi dirinya sedemikian rupa sehingga gelombang protes justru memiliki efek memperbaiki. Kekuatan proyek-proyek hukum humanis dan responsif seperti justice for the poor, mampu mengintegrasikan resistensi terhadap kapitalisme menjadi masuk dalam sistem.
\end{abstract}

Kata Kunci: ideologi, kapitalisme, justice for the poor

\section{Latar Belakang}

Ideologi memang berwajah ganda, seperti dikatakan Ernst Bloch yang dikutip ulang generasi penerusnya Douglas Kellner dalam artikel lepasnya "Ernst Bloch, Utopia and Ideology Critique" sebagai berikut,"For Bloch, ideology is "Janus-faced", two-sided: it contain errors, mystifications, and techniques of manipulation and domination, but it also contains a utopian residue or surplus that can be used for social critique and to advance progressive politics."
Ideologi tidak pernah datang dari ide penganutnya, karena umumnya bukan hasil refleksi melainkan doktriner sehingga mengerdilkan daya kritis penganutnya. Untuk mengatasi penyakit ideologi, ia harus terus dikritik (kritik-otokritik) sehingga tidak dominan. Ideologi seperti "pharmacon", ular yang membelit dalam gelas whiski: bisa sebagai obat sekaligus racun. Di balik sisi gelapnya yang ortodoks, ideologi membawa kegairahan dialektik di bidang ekonomi, sosial, politik, budaya, dan hukum.

1. Douglas Kellner, Ernst Bloch, Utopia and Ideology Critique (online), http://www.uta.edu/huma/illuminations/kell1.htm, diakses 24 November 2008. 
Paraideologkapitalisme, misalnya, berlombalomba melahirkan teori-teori modernisasi dan pembangunan untuk membendung pengaruh sosialisme-komunisme dan antikapitalisme di negara-negara Ketiga. Uniknya dalam tubuh kapitalisme sendiri terjadi pertarungan teoritik antara Neo Klasik (Keynesian) yang masih menginginkan campur tangan negara (welfare state) dengan Neoliberalisme yang menghendaki kedaulatan pasar sepenuhnya. Dialektika saudara ini "diselesaikan" Neoliberalisme dengan pembagian peran: Milton Friedman melucuti pemikiran ekonomi Neo Klasik ${ }^{2}$ dan Frederick von Hayek melawan sosialis-komunis ${ }^{3}$ dengan ditunjang lembaga dana internasional (World Bank, IMF, WTO, dan sebagainya).

Di sisi yang berseberangan, para teoritisi sosialis-komunis melahirkan teori-teori yang menelanjangi keserakahan kapitalisme sekaligus kritik (anti) terhadap kapitalisme seperti teori "Materialisme-Dialektika-Historis" (Karl Marx), teori "Strukturalis" (Althusser), teori "Hegemoni" (Antonio Gramsci), dan teori ketergantungan (Samir Amin, Ande Gunder Frank, dan sebagainya) Selain itu, dalam kelompok "kiri" muncul teori "Kritis" (Max Hocheimer, Theodore W. Adorno, Herbert Marcuse, dan sejumlah penerusnya). Para teoritisi tersebut berusaha menyingkap dan menyobek selubung-selubung ideologis yang menutupi kenyataan tak manusiawi dari kesadaran manusia.

Di luar kubu kapitalisme dan sosialisme, muncul Posmodernisme sebagai kritik terhadap modernisme dan keluar dari tradisi enlightenment. Meski beraneka warna, filsafat bernapaskan posmodernisme bersatu dalam penolakan "ceritacerita besar" (grand narrative) penyelamatan manusia, menolak pemikiran dikotomis (binary opposition), dan menolak obyektivitas ilmu pengetahuan. Penekanan posmodernisme pada right of different (hak untuk berbeda) sehingga tidak ada kebenaran tunggal (yang ada adalah "kebenaran dan kebenaran”). Dengan gaya dekonstruksinya, posmodernisme memutus (discontinuity) rantai perdebatan "kanan-kiri" beserta seluruh rasion- alitas yang membenarkannya. Akhir pertarungan, pemenangnya adalah kapitalisme. Kemenangan kapitalisme, menurut George Ritzer, disebabkan pendukungnya mempunyai kekuatan dan kekuasaan, bukan karena teori itu lebih manusiawi, lebih baik, apalagi lebih benar.

Namun kemenangan itu oleh sebagian pendukungnya diwartakan sebagai "kebenaran akhir". pewarta kebenaran itu salah satunya adalah Francis Fukuyama dalam "The End of History and The Last Man" menyebut zaman ini sebagai "titik akhir dari evolusi ideologis manusia dan bentuk final "pemerintahan manusia". Alasannya, telah terjadi kesepakatan luar biasa berkenaan dengan pengakuan terhadap demokrasi liberal sebagai sistem yang diterima di seluruh dunia. ${ }^{4}$

Uraian di muka memberikan gambaran bahwa ada permasalahan yang layak dibahas yaitu mengenai terjadinya pertarungan ideologi kapitalisme \& liberalisme dan sosialisme membawa pengaruh ke dalam perdebatan paradigma dalam ilmu hukum; dan strategi kapitalisme dalam berbagai kedoknya untuk mampu bertahan dari desakan kritik serta agar memberikan kesan yang lebih humanis terhadap negara sedang berkembang.

\section{Pembahasan}

\section{a. Ideologi dalam Hukum}

Dialektika paradigma dalam ranah hukum tidak lepas dari dialektika ideologi-ideologi, karena hukum juga merupakan produk ideologi tertentu. Perkembangan sistem hukum modern, misalnya, tidak bisa dilepaskan dari kelahiran industrialisasi kapitalistik. Hubungan hukum modern dan kapitalisme ibarat hubungan anak dengan ibunya. Max Weber termasuk perintis yang melihat hubungan antara munculnya hukum modern dengan kapitalisme, Weber dalam bukunya "Wirtschaft und Gesellschaft" melihat kapitalisme sebagai sebab terjadinya perubahan dalam tipe hukum dari tradisional menjadi moderen.

Kapitalisme menuntut suatu tatanan normatif dengan tingkat dapat diperhitungkan (calcula-

2. Milton Friedman, Capitalism and Freedom, University of Chicago Press, Chicago, 1962.

3. Hayek, F. A., The Fatal Conceit: The Errors of Socialism, W. W. Bartley III (Ed.), The Collected Works of F. A. Hayek, Routledge London and University of Chicago Press, Chicago, 1989.

4. Francis Fukuyama, The End of History and The Last Man, Penguin, London, 1992. 
bility) yang tinggi. Penelitian Weber terhadap sistem-sistem hukum yang ada pada waktu itu menyimpulkan, bahwa hanya hukum modern yang rasional, atau suatu rasionalitas formal yang bersifat logis, mampu memberikan tingkat perhitungan yang dibutuhkan. Legalisme memberikan dukungan kepada perkembangan kapitalisme dengan memberikan suasana yang stabil dan dapat diperhitungkan. ${ }^{5}$

Hukum moderen secara epistemik-falsafati mendapat nutrisi dari pemikiran Positivisme Hukum yang mulai tumbuh pada abad ke-18, sebelum kapitalisme dominan. Meskipun Positivisme Hukum yang hadir dalam wujud hukum modern dan kapitalisme merupakan 2 (dua) fenomena yang proses historisnya berbeda dan masing-masing berdiri sendiri, dalam perkembangannya kemudian antara hukum modern dan kapitalisme mempunyai pertalian erat.

Namun, lahirnya hukum modern bukan tanpa perlawanan. Yang paling gigih melakukan kritik terhadap mazhab Positivisme Hukum adalah Mazhab Sejarah Hukum yang dirintis oleh Friedrich Carl von Savigny (1779 - 1861), ahli hukum berkebangsaan Jerman. ${ }^{6}$ Pemikiran Savigny ini kemudian diteruskan oleh salah seorang muridnya yakni Pucta. Pengaruh mazhab Sejarah Hukum meluas ke Inggris dan dikembangkan oleh Henry Maine. Kelompok ini menyerang mazhab Positivisme Hukum dengan mengatakan bahwa hukum bukan hanya yang dibuat oleh penguasa dalam bentuk undang-undang namun hukum adalah jiwa bangsa (volkgeist) dan substansinya adalah aturan tentang kebiasaan hidup masyarakat. Hukum, menurut mazhab Hukum Sejarah, bukan diciptakan melainkan ditemukan. Perbedaan tajam antara mazhab Sejarah Hukum terhadap Positivisme Hukum terletak pada sumber dan bentuk hukum.

Ketegangan antara dua mazhab ini diredakan oleh mazhab Sociological Jurisprudence yang mencoba mengambil "jalan tengah" dengan mensintesakan basis argumentasi yang berkem- bang pada kedua mazhab itu. Tokoh dibalik mazhab Sociological Jurisprudence adalah Eugen Ehrlich dan Roscoe Pound. Ajaran dari Eugen Ehrlich bahwa hukum yang baik adalah hukum yang sesuai dengan hukum yang hidup di dalam masyarakat (the centre of gravity of legal developoment lis not in legislation, nor in juristic, nor in judicial decision, but in society). ${ }^{7}$

Rumusan tersebut menunjukan kompromi yang cermat antara hukum modern dan tertulis sebagai kebutuhan masyarakat hukum demi adanya kepastian hukum dengan living law sebagai wujud penghargaan terhadap pentingnya peranan masyarakat dalam pembentukan hukum. Dengan melihat hubungan timbal-balik antara hukum dengan masyarakat. Pound kemudian menemukan konsep "hukum sebagai alat untuk merekayasa sosial (law as a tool of social engineering), atau dengan kata lain, hukum sebagai suatu independent variable yang dapat menimbulkan dampak berbagai aspek kehidupan sosial. ${ }^{8}$

Mengamati dialektika paradigma-paradigma hukum tersebut, awalnya demi kepastian hukum, hukum adat dan budaya lokal digusur. Karena hukum modern memiliki kelengkapan yang jauh lebih baik dan terorganisasi, maka hukum adat lambat laun mudah disingkirkan. Namun bagi kapitalisme, mengandalkan hukum modern semata tentu tidak mungkin. Dalam suasana kemajemukan budaya seperti Indonesia, hukum modern yang berlaku umum dan menyamaratakan malah bisa mengundang resistensi. Untuk mengurangi resistensi dari kekuatan-kekuatan lokal, hukum modern perlu diperlunak dengan memasukkan "living law" sebagai salah satu syarat hukum yang baik.

Dalam konteks kepentingan kapitalisme, awalnya perkembangan kapitalisme mempunyai pertalian erat dengan Positivisme Hukum, terutama dalam kepentingan untuk memberikan kepastian hukum bagi iklim bisnis. Namun dalam perkembangannya, masyarakat semakin kompleks, perilaku dan praktik bisnis terlalu besar

5. David M. Trubek, Max Weber on Law and The Rise of Capitalism, Wiconsin Law Review, 1972, hlm. 740.

6. Von Savigny menerbitkan pamflet “Of The Vocation of Our Age for Legislation and Jurisprudence” (Mengenai Tugas Legislasi dan Ilmu Hukum di Masa Kita) menolak ide A.F.J. Thibaut tentang koodifikasi dan transplantasi Civil Code Perancis. Setiap bangsa, kata Von Savigny, mempunyai karakter dan jiwa kebangsaan (Volkgeist), karenanya hukum bangsa satu belum tentu cocok untuk bangsa lain. Lihat, H. Kantorowicz, Savigny and The Historical School of Law, Law Quarterly Review 53, 1937.

7. M.D.A. Freeman, Llyod's Introduction to Jurisprudence, Sweet\&Maxwell LTD, London, 2001, hlm. 659-700.

8. Ibid. 
untuk hanya dimasuk-masukkan ke dalam pasal undang-undang begitu saja.

Positivisme Hukum tidak cukup memadai mengawal bagi jalannya roda kapitalisme. Untuk memenuhi kebutuhan yang semakin kompleks, pada ranah teoritis tidak cukup lagi menggunakan optik preskriptif dan perlu menciptakan pendekatan yang lebih holistik, misalnya sociolegal (catatan: tentu tidak bisa digeneralisasi bahwa paradigma-paradigma hukum yang lahir selalu linier berhubungan dengan kepentingan kapitalisme).

Pendekatan teoritik socio-legal ini diturunkan pada praktek hukum, sebagai contoh, memperkenalkan pendekatan Penyelesaian Sengketa Alternatif. Bisnis membutuhkan pendekatan Penyelesaian Sengketa Alternatif dibanding jalur litigasi yang kaku, memakan waktu lama, dan biaya yang mahal. Dengan menggunakan Penyelesaian Sengketa Alternatif, para pelaku bisnis bisa menyelesaian sengketa bisnis secara 'winwin solution' sehingga bisa merawat hubungan jangka panjang dengan rekan bisnis lainnya. Tetapi pendekatan socio-legal tidak seluruhnya dimonopoli kapitalisme untuk melegitimasi kepentingannya, disisi lain socio-legal justru digunakan para aktivis gerakan, sebagian akademisi hukum, dan pengacara progresif untuk melawan kapitalisme. Critical Legal Studies Movement, misalnya, menelanjangi paradigma hukum liberal-kapitalis sampai pada ketelanjangannya yang tuntas. Meski pemikiran Critical Legal Studies beraneka warna, tetapi pemikiran ini pada dasarnya menolak anggapan ahli hukum konservatif dan liberal yang mengatakan hukum itu otonom terpisah dari politik dan ekonomi. ${ }^{9}$

Critical Legal Studies berpendapat bahwa hukum tidak netral dan obyektif, terutama sejak kehadiran hukum modern, hukum sengaja dibuat untuk memfasilitasi kepentingan-kepentingan tertentu. Sistem hukum liberal, misalnya, tidak dirancang untuk memikirkan dan memberikan keadilan yang luas kepada masyarakat, melainkan lebih menekankan perlindungan kebebasan individu misalnya, dengan mengkonstruksi asas dan doktrin hukum yang melindungi hak milik individu tertentu.

\section{b. Justice For The Poor: Proyek Hukum Humanis?}

Pengisapan dan eksploitasi kapitalisme global di negara-negara Ketiga yang selalu menjadi sasaran banyak kritik, ternyata belakangan ini melakukan langkah sebaliknya, yakni mengembangkan sebuah proyek keadilan untuk kaum lemah dan papa. Bank Dunia, misalnya, melalui program justice for the poor ${ }^{10}$ seolah hendak menjawab semua kritik bahwa tidak benar program-program Bank Dunia mengedepankan keuntungan semata dan tidak berpihak kepada kaum miskin dan tertindas.

Justice for the poor dikreasi oleh Bank Dunia untuk mempromosikan pengurangan kemiskinan di Indonesia, khususnya strategi pemberdayaan kaum miskin melalui bantuan hukum. Bagi Bank Dunia, program pemberdayaan dan penyadaran hukum merupakan instrumen penting rakyat miskin untuk mendapatkan akses keadilan. Munculnya justice for the poor di Indonesia tak terpisahkan dengan program global dalam Poverty Reduction Strategy Papers (PRSPs). ${ }^{11}$

Ketika kekuasaan hadir dalam wajah yang lebih humanis dan menawarkan bantuan, menjadi sulit untuk mengkritisinya, apalagi menolaknya. Pelaksanaan kekuasaan memang tidak pertamatama melalui kekerasan (Hobbes), bukan dalam

9. Lihat Mark Kelman, A Guide to Critical Legal Studies, Harvard University Press, Cambridge, 1987, hlm. 111-112. Bandingkan dengan Roberto Unger, Law in Modern Society, Free Press, New York, 1976, hlm. 180. Lihat juga Duncan Kennedy dalam David Kairys (Ed.), Politics of Law, Pantheon, New York, 1982, hlm. 47.

10. Program Justice for The Poor (selanjutnya disingkat Justice) adalah proyek Bank Dunia. Proyek ini dimulai sejak Juni 2002 dengan tujuan memperbaiki akses masyarakat, terutama kelompok miskin, terhadap keadilan, melalui mekanisme informal maupun formal. Tim Justice melakukan penelitian lapangan di Indonesia untuk mendapatkan gambaran tentang apa yang terjadi dan apa yang diharapkan oleh kelompok masyarakat miskin dari lembaga hukum dengan tujuan memahami dukungan apa yang mungkin diberikan demi mendorong terjadinya reformasi hukum di tingkat lokal. Tim Justice lebih menujukan reformasi hukum dengan perspektif dari masyarakat yang menjadi tujuan hukum tersebut, daripada terhadap institusi atau kerangka kerja hukumnya sendiri. Tim Justice juga mengambil pelajaran dari - dan membantu mendesain, pelatihan paralegal dan penyediaan pengacara bantuan hukum pro bono bagi masyarakat kurang mampu dalam rangka pelaksanaan beberapa proyek Bank Dunia yang telah ada. Lihat penjelasan Bank Dunia, Justice For The Poor, http://www. justiceforthepoor.or.id/index.php?option=com_content\&task=view\&id=9\&Itemid=86, diakses 24 November 2008.

11. Pada bulan September 1999, IMF dan Bank Dunia meluncurkan strategi baru untuk menjalankan agenda Neoliberalisme di dunia. Progam ini disebut dengan Poverty Reduction Strategy Paper - PRSP (Kertas Strategi Pengurangan Kemiskinan). PRSPs dianggap sebagai sebuah pendekatan baru yang dapat mengatasi kemiskinan dan pembangunan ekonomi di negara-negara dengan pendapat rendah. 
represi (Freud) atau pertarungan kekuatan (Machiavelli), melainkan hadir dalam wujud produktif (Foucault) dan hegemonik (Gramsci). Meminjam konsep hegemoni Gramsci, ide pokok dibelakang konsep ini adalah klaim, dominasi kelas penguasa tak hanya meliputi sarana-sarana produksi fisik tetapi juga dominasi atas sarana-sarana produksi simbolik. Penguasaan terhadap kekuatan produksi material direplikasikan pada tingkat ide-ide, yang terlihat dalam pengusaan sektor-sektor ideologis masyarakat seperti hukum, pendidikan, media, dan sebagainya. Hasilnya dahsyat; si tertindas menjadi penikmat atas ketertindasannya.

Justice for the poor merupakan kreasi hukum canggih Bank Dunia meminjam pendekatan sociolegal, maka dalam rangka kepentingan melakukan refleksi-kritis kita pun menggunakan pendekatan yang kurang lebih sama (optik socio-legal) untuk menyingkap selubung-selubung hegemoni dalam proyek ini dengan memulai sebuah pertanyaan; apa tujuan "sesungguhnya" proyek justice for the poor?

Pertama, kalau kita cermati program justice for the poor tidak pernah mempersoalkan property right (hak milik) sebagai akar persoalan kemiskinan, bahkan sikap yang paling moderat (baca: kompromis) sekalipun seperti membicarakan hak kelola sumber daya alam yang dalam kenyataannya timpang. Padahal salah satu asal-muasal persoalan adalah hak milik. Dalam masyarakat liberal hak milik merupakan nyawa kapitalisme. Sekritis apa pun dalam masyarakat liberal (seperti masyarakat boleh mempersoalkan apa saja tentang keadilan), tetapi hanya satu yang tidak boleh didebat: eksistensi hak milik. Hak milik dan kapitalisme bagaikan kembar siam yang tidak mudah diceraikan oleh operasi bedah apa pun, apalagi dinegosiasikan melalui program justice for the poor. ${ }^{12}$
Justice for the poor memang bukan ditujukan untuk merombak struktur kemiskinan, melainkan perkakas strategis yang cocok dikembangkan untuk mengeliminasi konflik dan radikalisasi massa yang dikhawatirkan mengganggu iklim investasi, bahkan apabila dibiarkan dapat menghancurkan sistem yang sudah mapan.

Justice for the poor "memoderasi" radikalisasi massa dan kemungkinan terjadinya gejolak sosial akibat tertutupnya akses masyarakat terhadap hukum melalui program revitalisasi bantuan hukum, paralegal, revitalisasi bantuan hukum, otonomi peradilan desa, dan sebagainya. Kuranglebih pesannya begini; "apabila ada penggusuran, tidak perlu melawan dengan cara-cara kekerasan, bukankah rakyat sudah melek hukum dan tahu bagaimana menyelesaikan sengketa secara litigasi maupun non litigasi?"'13 justice for the poor ibarat mengurangi rasa sakit tanpa menghilangkan penyakitnya. Itulah mengapa program justice for the poor lebih menekankan solusi melalui penyelesaian sengketa alternatif, paralegal, bantuan hukum, dan sebagainya.

Dalam sungai sejarah yang mengalir, untuk mengeliminasi radikalisasi massa, negara-negara kapitalisme maju dan lembaga keuangan internasional sebenarnya telah lama meneteskan dananya kepada rakyat miskin di negara-negara Ketiga dalam berbagai program pemberdayaan. Bantuan disalurkan untuk pemberdayaan masyarakat di Negara-negara Ketiga, diantaranya melalui LSM-LSM dan perguruan tinggi, dalam bentuk proyek pengentasan kemiskinan, good governance, antikorupsi, legislative drafting, studi hukum, pendidikan demokrasi dan pemilu. Melalui berbagai proyek pemberdayaan dan penyadaran hukum, kontradiksi si kaya dan si miskin ditahan, rasa sakit akibat penetrasi kapital dikurangi, supaya tidak meledak menjadi revolusi sosial.

12. Program justice for the poor di Nusa Tenggara Barat membangun posko bantuan hukum, namun tidak pernah mempersoalkan, apalagi melakukan advokasi, pencaplokan lahan masyarakat Tanaq Awu untuk proyek bandara internasional. Kasus penggusuran ini menyebabkan ribuan petani tiga desa (Tanaq Awu, Ketare, Penujak) kehilangan lahan pertanian subur, sejumlah petani yang melawan terkena tembakan dan dipenjara dengan tuduhan perbuatan tidak menyenangkan, dan perempuan hamil keguguran akibat kekerasan aparat. Wawancara dengan Direktur Lembaga Studi dan Bantuan Hukum NTB, Suhaimi, 10 Januari 2009.

13. Hukum alat efektif sebagai "engsel” sosial. Lawrence Fridman menyebut lima fungsi dari sistem hukum. Pertama, sebagai sistem kontrol. Dengan kata lain, sistem hukum berkaitan dengan perilaku yang mengontrol. Kedua, fungsi hukum sebagai penyelesaian sengketa (dispute settlement). Dengan kata lain sistem hukum adalah agen pemecah konflik dan juga agen penyelesaian sengketa. Ketiga, fungsi redistribusi (redistributive function) atau fungsi rekayasa sosial (social engineering). Fungsi ini mengarahkan penggunaan hukum untuk mengadakan perubahan sosial yang berencana yang ditentukan oleh pemerintah. Keempat, hokum berfungsi sebagai pemelihara sosial (social maintenance). Kelima, hukum berfungsi mengawasi penguasa itu sendiri. Lawrence Friedman, American Law an Introduction (Second Edition), Hukum Amerika Sebuah Pengantar, Terjemahan Wishnu Basuki, Tata Nusa, Jakarta, 2001, hlm. 11-18. 
Kapitalisme tidak hadir dalam wajah aslinya: serakah, melainkan lebih humanis melalui "tangan kirinya" mengembangkan program "justice for the poor", "corporate social responsibility", dan sebagainya. Program-program humanis seperti justice for the poor menjadi sangat penting sebagai instrument untuk mendapatkan legitimasi publik melalui kosensus para pihak. justice for the poor adalah harga yang harus dibayar oleh agen-agen kapitalisme karena dalam suasana yang relatif demokratis ini tidak mungkin melakukannya secara otoritarian. Model lama yang represif seperti proyek Bank Dunia dalam pembuatan waduk Kedung Ombo tidak lagi efektif. Berbeda dengan jaman rezim otoriter Orde Baru, dirigennya tunggal sehingga memungkinkan untuk main tunjuk tanpa harus berunding dan meminta persetujuan masyarakatnya.

Kedua, penelitian Wiratraman ${ }^{14}$ menunjukan, akses keadilan dalam program justice for the poor lebih ditujukan pada efektivitas sistem hukum untuk kepentingan Bank Dunia itu sendiri. dalam urusan pemantauan korupsi, Bank Dunia sendiri memilih memfokuskan lebih banyak pada proyek-proyek yang didanainya sendiri seperti Proyek Pengembangan Kecamatan (PPK). Hal ini penting bagi Bank Dunia untuk menyelamatkan dana tersebut sekaligus meyakinkan pengembalian utang dalam jangka waktu tertentu. Namun uniknya, dana proyek-proyek pengawasan tersebut juga harus dibebankan melalui utang dimana lagilagi rakyat yang harus melunasinya. Pada titik ini "alat" telah mengkoloni "tujuan" sehingga peran Bank Dunia menjadi kabur antara filantropi, keswadayaan, atau mencari keuntungan ekonomis melalui program bercorak humanis.

Ketiga, justice for the poor seolah sebagai tindakan kapitalisme melawan dirinya sendiri dengan berbalik membela kaum miskin yang tertindas. Padahal yang sesungguhnya terjadi, tidak mengubah hubungan-hubungan yang eksploitatif. Sebagai analogi, dalam sejarahnya belum pernah peternak menelantarkan sapi perahnya. Peternak menyediakan rumput yang sehat, kandang yang bersih, dimandikan agar sapi tetap sehat dan susunya semakin melimpah untuk diperah. justice for the poor ini bersifat ideologis karena tidak bisa dilihat sebagai program yang otonom dan terpisah dari kepentingan-kepentingan dan program-program Bank Dunia yang lain seperti pasar tanah, pengamanan investasi, dan lain-lain, melainkan saling berkait, menguatkan dan mengakumulasi. One form capital comes tobe added to other form capital. ${ }^{15}$

\section{Kesimpulan}

Dalam masyarakat kapitalis yang relatif demokratis, pendekatan hukum represif mulai ditinggalkan dan beralih ke tatanan hukum yang lebih responsif dan humanis. Oposisi dalam masyarakat tidak dicegah atau dibungkam, melainkan di"biayai" untuk terus mengkritik kelemahan-kelemahan kapitalisme. Kritik justru dibutuhkan oleh kapitalisme untuk memodifikasi dirinya sedemikian rupa sehingga gelombang protes justru memiliki efek memperbaiki. Kekuatan-kekuatan perlawanan, pada akhirnya diintegrasikan dalam sistem sehingga kehilangan sayap negasinya. ${ }^{16}$

Sebagai kritik-otokritik, pendekatan SocioLegal yang semula merupakan pendekatan kritis atas kelemahan Positivisme Hukum (Dogmatika Hukum), dalam perkembangannya juga diserap oleh kapitalisme terutama untuk memodifikasi proyek-proyek mereka sehingga menjadi lebih humanis dan responsif. Kekuatan proyek-proyek hukum humanis dan responsif seperti Justice for The poor, mampu mengintegrasikan resistensi terhadap kapitalisme menjadi masuk dalam sistem.

14. R. Herlambang Perdana Wiratraman, Neo-Liberalisme, Good Governance dan Hak Asasi Manusia, Jurnal Hukum Jentera, Januari-Maret 2007.

15. John Perkins bekas seorang economic hit man dalam "pengakuan dosanya" tersebut ia menulis: "Sementara itu, aku merenungkan sifat alami bantuan luar negeri, dan aku mempertimbangkan peran sah yang dapat dimainkan oleh negara-negara maju (DC-Developed Countries di dalam jargon Bank Dunia) untuk membantu mengurangi kemiskinan dan kesengsaraan di negara-negara terbelakang (LDCLess Developed Countries). Aku mulai bertanya-tanya kapan bantuan itu tulus dan kapan bantuan itu hanya tamak dan mengutamakan keuntungan dan kepentingan diri sendiri,". Lihat, John Perkins, Confessions of an Economic Hit Man, Berrett-Koehler Publishers. Inc., San Francisco, 2004.

16. Lenyapnya "negasi" terhadap sistem, menurut filsuf Herbert Marcuse, menyebabkan masyarakat dewasa ini adalah masyarakat satu dimensi. Dimensi kedua yang lenyap adalah perlawanan terhadap sistem. Sehingga, seluruh dimensi kehidupan mengarah ke satu tujuan saja, yaitu menjaga kelangsungan system teknologis yang telah menjadi penguasaan total. Lihat; Herbert Marcuse, One Dimensional Man: Studies in The Ideology of Advanced Industrial Society, Routledge \& Kegan Paul, London, 1964. 
Dalam senjakala ideologi atau "titik akhir dari evolusi ideologis manusia", kita memang sedang menghadapi jalan buntu, sehingga memilih jalan memutar, yakni sambil menuntun kuda balap tua mengitari jalan lama: konsensus mengerjakan proyek hukum humanis dengan meminta sedekah pada para funding.

\section{DAFTAR PUSTAKA}

\section{Buku}

Friedman, Lawrence, 2001, American Law an Introduction (Second Edition), Hukum Amerika Sebuah Pengantar, Terjemahan Wishnu Basuki, Tata Nusa, Jakarta.

Freeman, M.D.A., 2001, Llyod's Introduction to Jurisprudence, Sweet\&Maxwell LTD, London.

Friedman, Milton, 1962, Capitalism and Freedom, University of Chicago Press, Chicago.

Francis Fukuyama, 1992, The End of History and The Last Man, Penguin, London.

Hayek, F. A., 1988, The Fatal Conceit: The Errors of Socialism. W. W. Bartley III (Ed.), The Collected Works of F. A. Hayek. Routledge London and University of Chicago Press, Chicago.

Kelman, Mark 1987, A Guide to Critical Legal Studies, Harvard University Press, Cambridge.

David Kairys, (Ed.), 1982, Politics of Law, Pantheon, New York.

Marcuse, Herbert, 1964, One Dimensional Man: Studies in The Ideology of Advanced Industrial Society, Routledge\&Kegan Paul, London.
Perkins, John, 2004, Confessions of an Economic Hit Man, Berrett-Koehler Publishers. Inc., San Francisco.

Unger, Roberto, 1976, Law in Modern Society, Free Press, New York.

Jurnal

H. Kantorowicz, 1937, Savigny and The Historical School of Law, Law Quarterly Review 53.

Trubek, David M., 1972, Max Weber on Law and The Rise of Capitalism, Wiconsin Law Review.

Wiratraman, 2007, Herlambang Perdana, NeoLiberalisme, Good Governance dan Hak Asasi Manusia, Jurnal Hukum Jentera, Januari-Maret 2007.

\section{Artikel Internet}

Bank Dunia, Justice For The Poor, http:// www.justiceforthepoor.or.id/index. php?option $=$ com_content\&task=view\&id $=9 \&$ Itemid $=86$. 